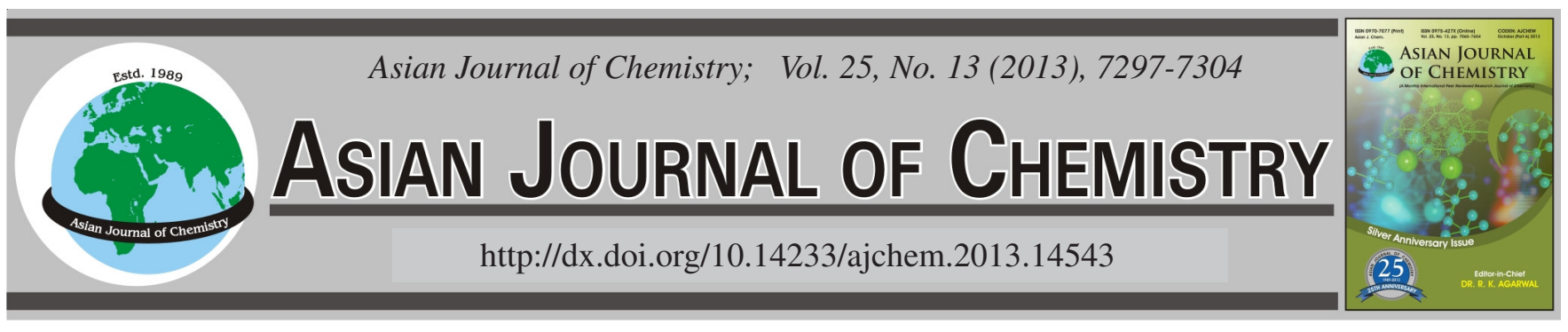

\title{
Synthesis, Biological Evaluation and Study of the Effect of Various N-Substituents on the Thermal Stabilities of Some New Diethanolamine Derivatives
}

\author{
Muhammad Yar ${ }^{1, *}$, Nafeesa Mushtaq ${ }^{1}$, Sadia Afzal ${ }^{1}$, Abdul Samad Khan ${ }^{1}$, Islam Ullah Khan ${ }^{2}$, \\ Muhammad Nadeem Akhter ${ }^{3}$, Seema Zareen ${ }^{3}$, Sohail Anjum Shahzad ${ }^{4}$, Zulfiqar Ali Khan ${ }^{5}$, \\ Syed Ali Raza Naqvi ${ }^{5}$, Nasir Mahmood ${ }^{6}$, Lubna TahiR ${ }^{7}$ and Muhammad Saleem ${ }^{7}$
}

\begin{abstract}
${ }^{1}$ Interdisciplinary Research Centre in Biomedical Materials, COMSATS Institute of Information Technology, Lahore, Pakistan ${ }^{2}$ Materials Chemistry Laboratory, Department of Chemistry, GC University Lahore, Pakistan

${ }^{3}$ Faculty of Industrial Science \& Technology, Universiti Malaysia Pahang, Lebuhraya, Tun Razak 26300 Gambang, Kauntan, Malaysia

${ }^{4}$ Department of Chemistry, COMSATS Institute of Information Technology, Abbottabad-22060, Pakistan

${ }^{5}$ Department of Chemistry, Government College University, Faisalabad-38000, Pakistan

${ }^{6}$ Department of Allied Health Sciences and Chemical Pathology, University of Health Sciences, Lahore, Pakistan

${ }^{7}$ Pharmeceutical Section, Applied Chemistry Research Centre, PCSIR Laboratories Complex, Lahore, Pakistan
\end{abstract}

*Corresponding author: Fax: +92 42 235321090; Tel: +92 42 111001007; Ext.: 829; E-mail: drmyar@ ciitlahore.edu.pk

\begin{abstract}
Diethanolamine and its derivatives are of considerable interest in medicinal and other industrial products. A series of new diethanolamine derivatives has been synthesized and characterized by ${ }^{1} \mathrm{H}$ NMR, ${ }^{13} \mathrm{C}$ NMR, FTIR and mass spectrometry. All synthesized compounds have been tested for their in vitro antibacterial activity against pathogenic microorganisms Escherichia coli, Staphylococcus aureus, Micrococcus luteus, Pseudomonas aeruginosa, Bacillus subtilis, Pasteurrella mutocida, Rhizopus oryzae and Salmonella typhi. Among the tested compounds, compounds $\mathbf{2 a}, \mathbf{2 b}, \mathbf{2} \mathbf{c}, \mathbf{3} \mathbf{a}$ and $\mathbf{4 b}$ have been found to be most potent members, which inhibited most of the pathogens used in the assay. Diethanolamine must posses tosyl or trifluoro groups in order to have good antimicrobial activities. All synthesized derivatives exhibited average FRAP activity and considerably good metal chelating activity and compound 2c showed excellent ABTS radical scavanging among all tested derivatives. Thermal stability and the effect of various N-protected groups on the thermal stability and degradation of selected diethanolamine derivatives (free flowing oils at room temperature and solid derivative 2a) has been studied by TGA and DSC analysis.
\end{abstract}

Key Words: Diethanolamine, Antioxidant activity, Antibacterial, DSC, TGA.

\section{INTRODUCTION}

Diethanolamine and its derivatives have wide applications in pharmaceuticals, surfactants formation, polishers and cosmetics industries. Diethanolamine has been used as intermediate in the rubber chemicals industry and as an emulsifier and dispersing agent in various agricultural products ${ }^{1,2}$ and also used in adhesives, cements, coatings, electroplating, printing inks, paints, papers, petroleum, coal and polymer productions, textile finishing and lubricants ${ }^{3}$. The use of lubricants is crucial and plays an important role in our daily lives. The search for new lubricants particularly liquid and stable at high temperature is highly desired. TGA/DSC have successfully been utilized for determination of physical properties and study of chemical reactions ${ }^{4-8}$ and for investigation of thermal stabilities of compounds ${ }^{9,10}$. Diethanolamine derivatives have previously been in high concern due to their fuel lubricity view point. However there are limited TGA and DSC analysis performed for diethanolamine and its derivatives to predict their thermal stabilities. They have essential contribution to mantain required lubricating properties ${ }^{11}$.

The increasing resistance of pathogens to current antimicrobial agents is a dilemma and fungal infections are also serious issue of concern ${ }^{12}$. Antioxidants are widely used and have been investigated for direct and indirect prevention of diseases such as cancer, diabetes mellitus, coronary heart disease and even altitude sickness. Antioxidants have also been used in food industry to prevent deterioration, nutritional losses and as flavoring agents in various foods ${ }^{13}$. Diethanolamine and its derivatives constitute an important class of heteroatom compounds as they have attracted significant interest in medicinal chemistry. Diethanolamine derivatives possess vibrant 
spectrum of biological activities including antibacterial ${ }^{14}$, anticancer ${ }^{15}$, local anesthetic ${ }^{16}$, antiplatelet aggregation ${ }^{17}$ and antioxidant properties ${ }^{18}$ antituberculosis ${ }^{19}$. Such promising biological potentials of diethanolamine and its derivatives have prompted us to devise, synthesize and biologically evaluate a new series of compounds with potent antimicrobial and antioxidant potential and also to test their thermal properties.

\section{EXPERIMENTAL}

All the solvents were used as obtained, except THF and $\mathrm{Et}_{2} \mathrm{O}$ were dried over sodium in benzophenone. TLC was performed on silica coated aluminium plates $\left(6 \mathrm{~F}_{254}, 0.2 \mathrm{~mm}\right)$. IR spectra were recorded on a JASCO A-302 IR spectrophotometer. ${ }^{1} \mathrm{H}$ and ${ }^{13} \mathrm{C}$ NMR spectra were recorded on Bruker NMR $500 \mathrm{MHz}$ and chemical shifts were calculated with reference to $\mathrm{CDCl}_{3}$ (7.25). Mass spectra were recorded on a Varian MAT 312 double focusing spectrometer, connected to an IBMAT compatible PC computer system. Standard antioxidants such as Trolox (6-hydroxy-2,5,7,8-tetramethylchroman-2carboxylic acid), iron(II) sulphate, 2,4,6-tri(2-pyridyl)-s-triazine (TPTZ), ferrozine, 2,2'-azinobis(3-ethylbenzothiazoline-6sulfonic acid) (ABTS) were purchased from Fluka (UK). HPLC grade ethanol was purchased from Rathburn Chemicals Ltd. (Walkerburn, Peebleshire, Scotland). Spectrophotometric measurements were made on UV-1700 PharmaSpec. UV-visible spectrophotometer, Shimadzu, Japan equipped with temperature control device. All the solutions were made in triplicate and experiments were performed three times. The results obtained were averaged. Thermogravimetric analysis (TGA) and differential scanning microscopy (DSC) analyses of all derivatives were carried out from $15-450{ }^{\circ} \mathrm{C}$ at a heating rate of $20^{\circ} \mathrm{C} \mathrm{min}^{-1}$ in nitrogen atmosphere using SDT Q-600. Dried alumina pan was used as a reference material and alumina sample holder $(90 \mu \mathrm{L})$ was employed for taking curves.

N,N-Bis(2-hydroxyethyl)-4-methylbenzenesulfonamide (2a): A solution of tosyl chloride $(7.56 \mathrm{~g}, 0.03 \mathrm{mmol})$ in $\mathrm{CH}_{2} \mathrm{Cl}_{2}(20 \mathrm{~mL})$ was added slowely to a stirred solution of diethanolamine ( $5 \mathrm{~g}, 0.04 \mathrm{mmol})$ in triethylamine $(12.1 \mathrm{~g}, 0.12$ $\mathrm{mmol}$ ) at room temperature. The reaction mixture was further stirred at room temperature for $4 \mathrm{~h}$. After completion of reaction, water $(15 \mathrm{~mL})$ was added in reaction mixture and extracted with $\mathrm{CH}_{2} \mathrm{Cl}_{2}(3 \times 15 \mathrm{~mL})$. Organic layers were combined, dried over anhydrous magnesium sulphate and filtered. The filterate was concentrated under vaccum which afforded the titled $\mathbf{2 a}$ as white crystaline solid (90\%); m.p. $92-94{ }^{\circ} \mathrm{C} ; \mathrm{R}_{\mathrm{f}}, 0.13$ (1:1; $n$-hexane and ethyl acetate); $\lambda_{\max }$ (neat, $\left.v_{\max }, \mathrm{cm}^{-1}\right): 3523-3241$ (O-H), 3030-2925 (C-H, ar. and aliph.), 1595 (C-C Ar.), 1162 $(\mathrm{S}=\mathrm{O}), 1087$ (C-O), 714 (ar. C-S); ${ }^{1} \mathrm{H}$ NMR $\left(500 \mathrm{MHz}, \mathrm{CDCl}_{3}\right.$ ), $7.70(2 \mathrm{H}, \mathrm{d}, J=8.2$, Ar-H), 7.33 (2H, d , $J=8.2$, Ar-H), 3.86 $\left(4 \mathrm{H}, \mathrm{t}, J=4.8, \mathrm{CH}_{2} \mathrm{OH}\right), 3.26\left(4 \mathrm{H}, \mathrm{t}, J=4.8, \mathrm{CH}_{2}-\mathrm{N}\right), 2.43$ (3H, s, $\left.\mathrm{CH}_{3}-\mathrm{Ar}\right) ;{ }^{13} \mathrm{C}$ NMR (500 MHz; $\mathrm{CDCl}_{3}$ ) 143.7 (C), 135.2 (C), $129.83(\mathrm{CH}), 127.2(\mathrm{CH}), 62.2\left(\mathrm{CH}_{2} \mathrm{O}\right), 52.94\left(\mathrm{CH}_{2}\right)$, $52.86\left(\mathrm{CH}_{2}\right), 21.48\left(\mathrm{CH}_{3}\right)$.

2,2,2-Trifluoro-N,N-bis(2-hydroxyethyl)acetamide (2b): Trifluroacetic anhydride (4.39 g, $20.94 \mathrm{mmol}$ ) was added drop wise to a stirred solution of diethanolamine ( $2 \mathrm{~g}, 19.04$ $\mathrm{mmol})$ in THF $(10 \mathrm{~mL})$. The reaction mixture was further stirred at room temperature for $6 \mathrm{~h}$. The solvent was evaporated uder vaccum, then water $(15 \mathrm{~mL})$ was added to residue and extracted with ethyl acetate $(3 \times 30 \mathrm{~mL})$. The organic layers were combined, dried over anhydrous magnesium sulphate and filtered. After evaporation of ethyl acetate under vaccum, 2b was obtained as colourless liquid (58\%); $\mathrm{R}_{\mathrm{f}} 0.11$ (1:1; $n$-hexane and ethyl acetate); ${ }^{1} \mathrm{H} \mathrm{NMR}\left(500 \mathrm{MHz}, \mathrm{CDCl}_{3}\right) ; 3.85$ (4H, br s, $\left.\mathrm{CH}_{2}-\mathrm{O}\right), 3.19$ (4H, br s, $\left.\mathrm{CH}_{2}-\mathrm{N}\right) ;{ }^{13} \mathrm{C}$ NMR $(500$ $\left.\mathrm{MHz} ; \mathrm{CDCl}_{3}\right)$ 157.4 (C), $115.8(\mathrm{C}), 49.7\left(\mathrm{CH}_{2}\right), 49.5\left(\mathrm{CH}_{2}\right)$, $59.4\left(\mathrm{CH}_{2}\right), 59.0\left(\mathrm{CH}_{2}\right)$.

Phenyl bis(2-hydroxyethyl)carbamate (2c): Diethanolamine $(1.0 \mathrm{~g}, 9.52 \mathrm{mmol})$ was added to a stirred solution of $\mathrm{NaHCO}_{3}(0.79 \mathrm{~g}, 10.47 \mathrm{mmol})$ in water $(10 \mathrm{~mL})$. The solution was further stirred at room temperature for $15 \mathrm{~min}$. Then phenoxylchloroformate $(1.48 \mathrm{~g}, 9.52 \mathrm{mmol})$ was added drop wise. The reaction mixture was further stirred for $5 \mathrm{~h}$ at room temperature. The reaction mixture was extracted with ethyl acetate $(3 \times 30 \mathrm{~mL})$. The organic layers were combined, dried over anhydrous magnesium sulphate and filtered. On evaporating solvent, $2 \mathrm{c}$ was obtained as colourless liquid $(51 \%) ; \mathrm{R}_{\mathrm{f}}$ 0.16 (1:1; $n$-hexane and ethyl acetate); ${ }^{1} \mathrm{H}$ NMR $(500 \mathrm{MHz}$, $\mathrm{CDCl}_{3}$ ) 7.08-7.36 (5H, m, ArH), 3.81 (4H, t, $\left.J=4.5, \mathrm{CH}_{2} \mathrm{O}\right)$, $3.58\left(4 \mathrm{H}, \mathrm{t}, J=4.5, \mathrm{CH}_{2} \mathrm{~N}\right) ;{ }^{13} \mathrm{C} \mathrm{NMR}\left(500 \mathrm{MHz} ; \mathrm{CDCl}_{3}\right)$ $155.0(\mathrm{C}), 150.9(\mathrm{C}), 129.3(\mathrm{CH}) 125.4(\mathrm{CH}), 121.0(\mathrm{CH})$, $60.8\left(\mathrm{CH}_{2}\right), 60.3\left(\mathrm{CH}_{2}\right), 52.2\left(\mathrm{CH}_{2}\right), 52.1\left(\mathrm{CH}_{2}\right)$.

N,N-Bis(2-hydroxyethyl)acetamide (2d): Acetic anhydride (1.06 g, $10.47 \mathrm{mmol})$ was added to a stirred solution of diethanolamine $(1.0 \mathrm{~g}, 9.52 \mathrm{mmol})$ in water $(10 \mathrm{~mL})$. The reaction mixture was stirred at room temperature for $3 \mathrm{~h}$. The reaction mixture was extracted with ethyl acetate $(3 \times 30 \mathrm{~mL})$. The organic layers were combined, dried over anhydrous magnesium sulphate and filtered. On evaporating solvent, 2d was obtained as yellowish liquid $(47 \%)$; ${ }^{1} \mathrm{H}$ NMR $(500 \mathrm{MHz}$, $\left.\mathrm{CDCl}_{3}\right) ; 4.23\left(2 \mathrm{H}, \mathrm{t}, J=6.0, \mathrm{CH}_{2}-\mathrm{O}\right), 4.21(2 \mathrm{H}, \mathrm{t}, J=6.0$, $\left.\mathrm{CH}_{2}-\mathrm{O}\right), 3.62\left(2 \mathrm{H}, \mathrm{t}, J=2.0, \mathrm{CH}_{2}-\mathrm{N}\right), 3.61(2 \mathrm{H}, \mathrm{t}, J=4.5$, $\left.\mathrm{CH}_{2}-\mathrm{N}\right), 2.15\left(3 \mathrm{H}, \mathrm{s}, \mathrm{CH}_{3}\right)$.

2,2'-(Tosylazanediyl)bis(ethane-2,1-diyl)bis(4-methylbenzenesulfonate) (3a): Sodium hydride (154 mg, $3.85 \mathrm{mmol}$ ) was added to a stirred solution of N,N-bis(2-hydroxyethyl)4-methylbenzene sulfonamide (2a) and tosyl chloride ( $0.6 \mathrm{~g}$, 3.24 mmol, 2.11 equiv.) in anhydrous $\mathrm{CH}_{2} \mathrm{Cl}_{2}(10 \mathrm{~mL})$. The reaction mixture was stirred at room temperature for $3 \mathrm{~h}$. Then reaction mixture was quenched with water $(15 \mathrm{~mL})$ and extracted with $\mathrm{CH}_{2} \mathrm{Cl}_{2}(3 \times 15 \mathrm{~mL})$. The organic layers were combined, dried over anhydrous $\mathrm{MgSO}_{4}$ and concentrated under vaccum, 3a was obtained as white solid (65\%); $\mathrm{R}_{\mathrm{f}} 0.20$ (7:3; $n$-hexane and ethyl acetate): m.p. $81-82^{\circ} \mathrm{C}$; (neat, $\mathrm{v}_{\max }$, $\mathrm{cm}^{-1}$ ): 3030-2923 (C-H, ar. and aliph.), 1595 (C-C Ar.), 1361 (S-O), 1162 (S=O), 1095 (C-O), 720-815 (ar. C-S); ${ }^{1} \mathrm{H}$ NMR $\left(500 \mathrm{MHz}, \mathrm{CDCl}_{3}\right)$ 7.26-7.76 (12H, m, ArH), $4.11(4 \mathrm{H}, \mathrm{t}, J=$ 6.0, $\left.\mathrm{CH}_{2}-\mathrm{O}\right), 3.37\left(4 \mathrm{H}, \mathrm{t}, J=6.0, \mathrm{CH}_{2}-\mathrm{N}\right), 2.44\left(9 \mathrm{H}, \mathrm{s}, \mathrm{CH}_{3}-\right.$ $\mathrm{Ar}) ;{ }^{13} \mathrm{C} \mathrm{NMR}\left(500 \mathrm{MHz} ; \mathrm{CDCl}_{3}\right) 144.9$ (C), 144.8 (C), 143.8 (C), $135.0(\mathrm{C}), 132.1(\mathrm{CH}), 132.1(\mathrm{CH}), 129.7(\mathrm{CH}), 129.6$ $(\mathrm{CH}), 129.4(\mathrm{CH}), 127.6(\mathrm{CH}), 126.9(\mathrm{CH}), 65.9\left(\mathrm{CH}_{2}\right), 65.8$ $\left(\mathrm{CH}_{2}\right), 48.1\left(\mathrm{CH}_{2}\right), 48.1\left(\mathrm{CH}_{2}\right), 21.3\left(\mathrm{CH}_{3}\right), 21.2\left(\mathrm{CH}_{3}\right), 21.1\left(\mathrm{CH}_{3}\right)$.

2-(N-(2-Hydroxyethyl)-4-methylphenylsulfonamido)ethyl 2-nitrobenzenesulfonate (3b): N-(2-Hydroxyethyl)-N(hydroxymethyl)-4-methylbenzene sulphonamide (2a) (100 mg, $0.386 \mathrm{mmol}$ ) was dissolved into dichloromethane $(4 \mathrm{~mL})$, then 
aquous solution of sodium hydroxide $(8 \mathrm{~mL}, 10 \mathrm{M})$ and 2nitrobenzene sulfonylchloride $(25 \mathrm{mg}, 0.11 \mathrm{mmol})$ were added to the reaction mixture. Then reaction mixture was refluxed for $12 \mathrm{~h}$, cooled to room temperature, quenched with water $(10 \mathrm{~mL})$ and extracted with dichloromethane $(3 \times 10 \mathrm{~mL})$. The combined organic layers were passed over the anhydrous magnesium sulphate, filtered and concentrated in vacuum to afford the 2-(N-(2-hydroxyethyl)-4-methylphenylsulfonamido) ethyl 2-nitrobenzene sulfonate as white solid (86.5\%), was washed with $n$-hexane to remove the excess benzene sulfonyl chloride; $\mathrm{R}_{\mathrm{f}} 0.37$ ( $1: 1 ; n$-hexane and ethyl acetate); m.p. 91-93 ${ }^{\circ} \mathrm{C}$; (neat, $\left.v_{\max }, \mathrm{cm}^{-1}\right)$ : 2852-3400 (C-H, ar. and aliph.), 1595.6 (C-C Ar.), 1365 (S-O), 1162 (S=O), 1087 (CO), 731-795 (ar. C-S); ${ }^{1} \mathrm{H}$ NMR (500 MHz, $\mathrm{CDCl}_{3}$ ) 7.30-8.15 $(8 \mathrm{H}, \mathrm{m}, \mathrm{ArH}), 4.40\left(2 \mathrm{H}, \mathrm{t}, J=6.0, \mathrm{CH}_{2}-\mathrm{O}\right), 3.74(2 \mathrm{H}, \mathrm{t}, J=$ $\left.4.5, \mathrm{CH}_{2}-\mathrm{O}\right), 3.5\left(2 \mathrm{H}, \mathrm{t}, J=6.0, \mathrm{CH}_{2}-\mathrm{N}\right), 2.98(2 \mathrm{H}, \mathrm{t}, J=4.5$, $\mathrm{CH}_{2}-\mathrm{N}$ ), 2.43 (3H, s, $\mathrm{CH}_{3}$ ); MS m/z (EI) 444; HRMS calcd. (\%) for $\mathrm{C}_{17} \mathrm{H}_{20} \mathrm{~N}_{2} \mathrm{O}_{8} \mathrm{~S}_{2}\left(\mathrm{M}^{+}\right)$444.0661, obs. 444.0556.

2,2'-(Tosylazanediyl)bis(ethane-2,1-diyl) dibenzenesulfinate (3c): N-(2-Hydroxyethyl)-N-(hydroxymethyl)-4methylbenzene sulphonamide (2a) (200 mg, $0.77 \mathrm{mmol}$ ), was dissolved in dichloromethane $(5 \mathrm{~mL})$. Then benzene sulphonyl chloride $(0.33 \mathrm{~mL}, 1.62 \mathrm{mmol})$ and aquous solution of sodium hydroxide $(4 \mathrm{~mL}, 10 \mathrm{M})$ was added and the reaction mixture was refluxed for $7 \mathrm{~h}$. Then reaction was quenched with water $(20 \mathrm{~mL})$ and extracted with dichloromethane $(3 \times 20 \mathrm{~mL})$. The combined organic layeres were passed over anhydrous magnesium sulphate, filtered and concentrated in vacuum to afford 2,2'-(tosylazanediyl)bis(ethane-2,1-diyl) dibenzene sulfinate (3c) as white solid $(96 \%) ; \mathrm{R}_{\mathrm{f}} 0.65(1: 1 ; n$-hexane and ethyl acetate); m.p. $107-108{ }^{\circ} \mathrm{C}$; (neat, $\left.v_{\max }, \mathrm{cm}^{-1}\right)$ : 3411 2924 (C-H), 1596 (C-C ), 1358 (S-O), 1169 (S=O), 1095 (CO), 730-810 ( C-S); ${ }^{1} \mathrm{H}$ NMR (500 MHz, $\mathrm{CDCl}_{3}$ ), 7.56-7.89 $(12 \mathrm{H}, \mathrm{m}, \mathrm{ArH}), 4.14$ (4H, t, $\left.J=6.0, \mathrm{CH}_{2}-\mathrm{O}\right), 3.38$ (4H, t, $J=$ 6, $\left.\mathrm{CH}_{2}-\mathrm{N}\right), 2.43$ (3H, s, $\mathrm{CH}_{3}$ ); MS m/z (EI) 539; HRMS calcd. (\%) for $\mathrm{C}_{23} \mathrm{H}_{25} \mathrm{NO}_{8} \mathrm{~S}_{3}\left(\mathrm{M}^{+}\right) 539.0742$, obs. 539.0734.

2,2'-(2,2,2-Trifluoroacetylazanediyl)bis(ethane-2,1diyl) bis (4 methylbenzenesulfonate) (3d): Tosyl chloride (2.0 g, $10.9 \mathrm{mmol}$ ) was added slowly to a stirred solution of 2,2,2trifluoro-N,N-bis(2-hydroxyethyl)acetamide (2b) (1.0 g, 4.97 mmol) in $\mathrm{CH}_{2} \mathrm{Cl}_{2}(15 \mathrm{~mL})$. Then aquous $\mathrm{NaOH}$ solution (10 $\mathrm{mL}, 10 \mathrm{M}$ ) was added and refluxed for $5 \mathrm{~h}$. Reaction mixture was quenched with water $(25 \mathrm{~mL})$ and extracted with dichloromethane $(3 \times 20 \mathrm{~mL})$. The organic layers were combined, dried over anhydrous magnesium sulphate, filtered and concentrated in vaccum to afford $\mathbf{3 d}$ as white solid $(60 \%) ; \mathrm{R}_{\mathrm{f}}$ 0.21 (7:3; $n$-hexane and ethyl acetate); m.p. $47-49{ }^{\circ} \mathrm{C}$; (neat, $\left.v_{\max }, \mathrm{cm}^{-1}\right)$ : 2927-3400 (C-H.), 1767 (C=O), 1598 (C-C), 1357 (S-O), 1167 (S=O), 1095 (C-O), 734-815 (C-S); ${ }^{1} \mathrm{H}$ NMR (500 $\left.\mathrm{MHz}, \mathrm{CDCl}_{3}\right)$ 7.30-7.77 (8H, m, ArH) $4.11\left(4 \mathrm{H}, \mathrm{t}, J=6, \mathrm{CH}_{2} \mathrm{O}\right)$, $3.37\left(4 \mathrm{H}, \mathrm{t}, J=6, \mathrm{CH}_{2}-\mathrm{N}\right), 2.46\left(3 \mathrm{H}, \mathrm{s}, \mathrm{CH}_{3}\right), 2.43(3 \mathrm{H}, \mathrm{s}$, $\mathrm{CH}_{3}$ ); MS m/z (EI) 509; HRMS calcd. (\%) for $\mathrm{C}_{23} \mathrm{H}_{25} \mathrm{NO}_{8} \mathrm{~S}_{3}$ $\left(\mathrm{M}^{+}\right)$509.0790, obs. 539.0779.

2,2'-(Acetylazanediyl)bis(ethane-2,1-diyl)bis(4methylbenzene sulfonate) (3e): Tosyl chloride (3.23 g, 17 mmol) was added slowly to a stirred soultion of N,N-bis(2hydroxyethyl)acetamide (2d) $(1.0 \mathrm{~g}, 6.8 \mathrm{mmol})$ in $\mathrm{CH}_{2} \mathrm{Cl}_{2}$ $(10 \mathrm{~mL})$. Then aquous solution of sodium hydroxide $(10 \mathrm{~mL}$,
$10 \mathrm{M}$ ) was added and refluxed for $5 \mathrm{~h}$. Reaction mixture was quenched with water $(20 \mathrm{~mL})$ and extracted with dichloromethane $(3 \times 20 \mathrm{~mL})$. The combined organic layers were dried over anhydrous magnesium sulphate, filtered and concentrated in vacuum to afford $3 \mathbf{e}$ as white solid (53\%); $\mathrm{R}_{\mathrm{f}} 0.20$ (7:3; $n$-hexane and ethyl acetate); m.p. $61-63{ }^{\circ} \mathrm{C}$; (neat, $\left.\mathrm{v}_{\max }, \mathrm{cm}^{-1}\right)$ : 3428-2926 (C-H), 1770 (C=O), 1597 (C-C), 1353 (S-O), 1176 $(\mathrm{S}=\mathrm{O}), 1094$ (C-O), 723-814 (C-S); ${ }^{1} \mathrm{H}$ NMR (500 MHz, $\left.\mathrm{CDCl}_{3}\right), 7.31-7.76(8 \mathrm{H}, \mathrm{m}, \mathrm{ArH}), 4.11\left(4 \mathrm{H}, \mathrm{t}, J=5.5, \mathrm{CH}_{2}-\mathrm{O}\right)$, $3.37\left(4 \mathrm{H}, \mathrm{t}, J=5.5, \mathrm{CH}_{2}-\mathrm{N}\right), 2.46\left(3 \mathrm{H}, \mathrm{s}, \mathrm{CH}_{3}\right), 2.43(3 \mathrm{H}, \mathrm{s}$, $\mathrm{CH}_{3}$ ); MS m/z (EI) 455; HRMS calcd. (\%) for $\mathrm{C}_{20} \mathrm{H}_{25} \mathrm{NO}_{7} \mathrm{~S}_{2}$ $\left(\mathrm{M}^{+}\right)$455.1072, obs. 455.1061.

2,2,2-Trifluoro-N,N-bis(2-(trifluoromethoxy)ethyl) acetamide (4b): 2,2,2-Trifluoro-N,N-bis(2-hydroxyethyl) acetamide (2b) $(0.50 \mathrm{~g}, 2.49 \mathrm{mmol})$ was added to a stirred solution of trifluoroaccetic acid $(1.44 \mathrm{~mL}, 0.01 \mathrm{mmol})$ in THF $(10 \mathrm{~mL})$. The reaction mixture was stirred at room temperature for $6 \mathrm{~h}$. After the completion of reaction solvent was evaporated on rotary evaporator, quenched with water and extracted with ethyl acetate $(3 \times 20 \mathrm{~mL})$. The obtained organic layers were combined obtained, dried over anhydrous magnesium sulphate, concentrated in vacuum to get 2,2,2-trifluoro-N,Nbis(2-(trifluoromethoxy)ethyl)acetamide (4b) as clear yellowish liquid of fuming nature $(90 \%) ; \mathrm{R}_{\mathrm{f}} 0.58(1: 1 ; n$-hexane and ethyl acetate); ${ }^{1} \mathrm{H}$ NMR (500 MHz, $\left.\mathrm{CDCl}_{3}\right), 4.4(4 \mathrm{H}, \mathrm{m} 2 \times$ $\left.\mathrm{CH}_{2}-\mathrm{O}\right), 3.65\left(2 \mathrm{H}, \mathrm{t}, J=5.5, \mathrm{CH}_{2}-\mathrm{N}\right), 3.49(2 \mathrm{H}, \mathrm{t}, J=5.5$, $\mathrm{CH}_{2}-\mathrm{N}$ ); $\mathrm{MS} \mathrm{m} / \mathrm{z}$ (EI) 393; HRMS calcd. (\%) for $\mathrm{C}_{10} \mathrm{H}_{8} \mathrm{~F}_{9} \mathrm{NO}_{5}$ $\left(\mathrm{M}^{+}\right)$393.0259, obs. 393.0247.

N,N-Bis(2-azidoethyl)-4-methylbenzenesulfonamide (5a): 2,2'-(Tosylazanediyl)bis(ethane-2,1-diyl)bis(4methylbenzenesulfonate) (3a) (2.0 g, $0.17 \mathrm{mmol})$ was dissolved in DMF ( $5 \mathrm{~mL})$. Then sodium azide $(24.07 \mathrm{mg}, 0.37 \mathrm{mmol})$ was added in the soultion and reaction mixture was heated at $80^{\circ} \mathrm{C}$ for $2 \mathrm{~h}$. After this reaction mixture was quenched with water $(15 \mathrm{~mL})$ and extracted with ethyl acetate $(3 \times 15 \mathrm{~mL})$. The combined organic layers were dried over anhydrous magnesium sulphate and concentrated under vaccum to afford $\mathrm{N}, \mathrm{N}$-bis(2-azidoethyl)-4-methylbenzenesulfonamide (5a) as white solid $(82 \%) ; \mathrm{R}_{\mathrm{f}} 0.52$ (1:1; $n$-hexane and ethyl acetate); m.p. $75-77{ }^{\circ} \mathrm{C}$; (neat, $\left.v_{\max }, \mathrm{cm}^{-1}\right)$ : 3395-2924 (C-H), 2121 $(\mathrm{N} \equiv \mathrm{N}), 1593(\mathrm{C}-\mathrm{C}), 1160(\mathrm{~S}=\mathrm{O}), 707-812(\mathrm{C}-\mathrm{S}) ;{ }^{1} \mathrm{H}$ NMR $\left(500 \mathrm{MHz}, \mathrm{CDCl}_{3}\right)$ 7.26-7.72 (4H, m, Ar-H), $3.5(2 \mathrm{H}, \mathrm{t}, J=$ 6.0, $\left.\mathrm{CH}_{2}-\mathrm{N}\right), 3.30\left(4 \mathrm{H}, \mathrm{t}, J=6.0, \mathrm{CH}_{2}-\mathrm{N}\right), 2.44\left(3 \mathrm{H}, \mathrm{s}, \mathrm{CH}_{3^{-}}\right.$ $\mathrm{Ar}) ;{ }^{13} \mathrm{C} \mathrm{NMR}\left(500 \mathrm{MHz} ; \mathrm{CDCl}_{3}\right) 144$ (C), 135.7 (C), 129.9 $(\mathrm{CH}), 127.2(\mathrm{CH}), 50.7\left(\mathrm{CH}_{2}\right), 48.9\left(\mathrm{CH}_{2}\right), 21.5\left(\mathrm{CH}_{3}\right), 21.4$ $\left(\mathrm{CH}_{3}\right)$.

2-(N-(2-Azidoethyl)acetamido)ethyl 4-methyl benzene sulfonate (5e): 2,2'-(Acetylazanediyl)bis(ethane-2,1-diyl)bis(4-methylbenzene sulfonate) (3e) (200 mg, $0.43 \mathrm{mmol})$ was dissolved in DMF (5 mL). Then sodium azide (62.45 mg, 0.96 mmol, 2.2 equiv.) was added to the solution and reaction mixture was heated at $80^{\circ} \mathrm{C}$ for $2 \mathrm{~h}$. After this reaction mixture was quenched with water $(15 \mathrm{~mL})$ and extracted with ethyl acetate $(3 \times 15 \mathrm{~mL})$. The combined organic layers were dried over anhydrous magnesium sulphate and concentrated under vaccumto afford N,N-bis(2-azidoethyl)acetamide (5e) as white solid (71 \%); m.p. $117-120{ }^{\circ} \mathrm{C}$; (neat, $v_{\max }, \mathrm{cm}^{-1}$ ): 3388-2915 (C-H), $2124(\mathrm{~N} \equiv \mathrm{N}), 1627(\mathrm{C}=\mathrm{O}) ;{ }^{1} \mathrm{H} \mathrm{NMR}\left(500 \mathrm{MHz}, \mathrm{CDCl}_{3}\right)$ 
7.64-7.39 (4H, m, ArH), 3.73(2H, t, $\left.J=5.0, \mathrm{CH}_{2}-\mathrm{O}\right), 2.99$ $\left(2 \mathrm{H}, \mathrm{t}, J=5.0, \mathrm{CH}_{2}-\mathrm{N}\right), 2.44\left(3 \mathrm{H}, \mathrm{s}, \mathrm{CH}_{3}\right), 1.256(2 \mathrm{H}, \mathrm{t}, J=$ $\left.5.0, \mathrm{CH}_{2}-\mathrm{N}\right), 0.92\left(2 \mathrm{H}, \mathrm{t}, J=5.0, \mathrm{CH}_{2}-\mathrm{N}=\mathrm{N}\right) ; \mathrm{MS} \mathrm{m} / \mathrm{z}(\mathrm{EI})$ 438; HRMS calcd. (\%) for $\mathrm{C}_{18} \mathrm{H}_{22} \mathrm{~N}_{4} \mathrm{O}_{5} \mathrm{~S}_{2}\left(\mathrm{M}^{+}\right)$438.1032, obs. 438.1025

\section{Antioxidant activity}

ABTS assay: ABTS radical cation was produced by a reaction between ABTS and potassium persulphate ( 7 and 2.45 $\mathrm{mM}$ final concentrations, respectively) and before its use the mixture was allowed to stand in the dark at room temperature for 12-16 $\mathrm{h}$. To study the antioxidant activity of samples, the ABTS stock solution was diluted with PBS buffer ( $\mathrm{pH} 7.4)$ to an absorbance of $0.70 \pm 0.02$ at $734 \mathrm{~nm}$ and equilibrated at 30 ${ }^{\circ} \mathrm{C}$. After addition of $10 \mu \mathrm{L}$ of sample to $2.99 \mathrm{~mL}$ of diluted ABTS $^{\circ+}$ solution $(\mathrm{A}=0.700 \pm 0.020)$, the absorbance was measured at $30{ }^{\circ} \mathrm{C}$ with exactly $1 \mathrm{~min}$ intervals for $6 \mathrm{~min}$. Appropriate solvent blanks were run in each assay for accurate readings. The percentage inhibition of absorbance was calculated by the following formula.

$$
\text { Inhibition }(\%)=\left(\frac{1-\mathrm{A}}{\mathrm{A}_{\mathrm{o}}}\right) \times 100
$$

where, $\mathrm{A}_{\mathrm{o}}$ is the absorbance at $734 \mathrm{~nm}$ of the negative control and $\mathrm{A}$ is the absorbance at $734 \mathrm{~nm}$ of the mixture with sample.

Ferric reducing power (FRAP) assay: The reducing capacity of derivatives was measured according to the reported method $^{20}$. Fresh FRAP solution was prepared by mixing 25 $\mathrm{mL}$ of $300 \mathrm{mM}$ acetate buffer (pH 3.6), $2.5 \mathrm{~mL}$ of $10 \mathrm{mM}$ tripyridyl triazine (TPTZ) solution in $40 \mathrm{mM} \mathrm{HCl}$ solution and $2.5 \mathrm{~mL}$ of $20 \mathrm{mM}$ ferric chloride solution. The mixture was incubated at $37^{\circ} \mathrm{C}$ throughout the monitoring period. 3000 $\mu \mathrm{L}$ of FRAP reagent was mixed with $100 \mu \mathrm{L}$ of sample and $300 \mu \mathrm{L}$ of distilled water. Absorbance was measured at 593 nm after 6 min.

$$
\text { Inhibition }=\frac{\mathrm{A}_{\mathrm{o}}}{0.025}
$$

where, $\mathrm{A}_{\mathrm{o}}$ is the absorbance taken at $593 \mathrm{~nm}$

Metal chelating assay: For metal chelating activity we followed the method of Denis et al. ${ }^{21}$. Sample solution (10 $\mathrm{mg} / \mathrm{mL}$ ) was prepared. Then $100 \mu \mathrm{L}$ of sample solution was added to a solution of $50 \mu \mathrm{L} \mathrm{FeSO}_{4}$. The reaction was initiated by the addition of ferrozine $(200 \mu \mathrm{L})$. The total volume of mixture was adjusted to $3650 \mu \mathrm{L}$ with ethanol. Then, the mixture was shaken vigorously and left at room temperature for $10 \mathrm{~min}$. Absorbance of the solution was then measured spectrophotometrically at $562 \mathrm{~nm}$. The percentage inhibition of absorbance was calculated by the following formula.

$$
\text { Inhibition }(\%)=\left(\frac{\left(\mathrm{A}_{0}-\mathrm{A}_{1}\right)}{\mathrm{A}_{0}}\right) \times 100
$$

where, $\mathrm{A}_{0}$ is the absorbance of the solution without sample at $562 \mathrm{~nm}$ and $\mathrm{A}_{1}$ is the absorbance in the presence of the sample. EDTA was used as a reference compound.

\section{Antimicrobial activity}

Test-microorganisms: Pathogenic microorganisms Escherichia coli, Staphylococcus aureus, Micrococcus luteus,
Pseudomonas aeruginosa, Bacillus subtilis, Pasteurrella mutocida Rhizopus oryzae and Salmonella typhi were used for in vitro antibacterial activity. These bacterial strains were obtained from Pakistan Council of Scientific and Industrial Research (PCSIR) Lahore.

Antibacterial assay: Agar well diffusion method was used to determine the antimicrobial activity ${ }^{22}$. The plates were autoclaved for $5 \mathrm{~h}$. We used nutrient agar $28 \mathrm{~g} / \mathrm{L}$ of distilled water. The media was poured in the petri dishes and allowed to solidify. The well was dug in the media using a sterile borer. The surface of the nutrient agar was inoculated by microbes using a sterile coton swab. The samples were introduced into respective wells. For each treatment, three replicates were maintained. Dichloromethane and the reference antibacterial and antifungal drug served as negative and positive controls, respectively. The plates were incubated immediately at $37^{\circ} \mathrm{C}$ for $24 \mathrm{~h}$. The activity was determined by measuring the diameter of the inhibition zone in millimeter. Growth inhibition was calculated with reference to the positive control. Standard deviation was also calculated.

The percentage inhibition was calculated as follows;

$$
\text { Inhibition }(\%)=\left(\frac{\mathrm{A}}{\mathrm{A}_{0}}\right) \times 100
$$

$\mathrm{A}=$ Area of inhibition of sample compound, $\mathrm{A}_{0}=$ Area of inhibition of standard drug (positive control) $\times 100$.

\section{RESULTS AND DISCUSSION}

Diethanolamine was used as a precursor which contains two hydroxyl groups and an amine group. All these groups are susceptible to acylation, alkylation and sulfonamide formation. Under mild reaction conditions in first step we were able to selectively attach only one acyl or sulfonyl group to nitrogen to synthesize $\mathbf{2 a - 2 d}$, following acylation on two hydroxyl groups of compound $\mathbf{2 b}$ gave $\mathbf{4 b}$. Derivatives $\mathbf{3 a - 3 e}$ were prepared from $\mathbf{2 a - 2 d}$ by reacting with different sulfonyl chlorides in the presence of excess $\mathrm{NaOH}$ and 1:1 mixture of dichloromethane and water. Compounds $\mathbf{3 a}$ and $\mathbf{3 e}$ yielded azides $\mathbf{5 a}$ and $\mathbf{5 e}$ by reacting with sodium azide in the presence of DMF. The reactions with azides were clean and completed in $2 \mathrm{~h}$ (Scheme-I). Derivatives $\mathbf{2 b - 2 d}$ and $\mathbf{4 b}$ were isolated as free flowing oils. We were able to easily synthesize 6 new comounds (3b-3e, $4 \mathbf{b}$ and $\mathbf{5 e})$.

Thermogravimetric analysis (TGA): One of the aim of this study was to synthesize new potential lubricants from diethanolamine. We were succesfull to prepare four free flowing oils (2b-2d, $\mathbf{4 b}$ ) which could be used as lubricants. Thermal stabilities of compounds $\mathbf{2 a - 2 d}$ and $\mathbf{4 b}$ were studied by TGA at heating rate of $20{ }^{\circ} \mathrm{C} \mathrm{min}{ }^{-1}$ under nitrogen atmosphere. For illustration, TGA curves of $\mathbf{2 a - 2 d}$ and $\mathbf{4 b}$ at heating rate of $20^{\circ} \mathrm{C} \mathrm{min}^{-1}$ are shown in Fig. 1 .

It was observed that different $\mathrm{N}$-substituents of diethanolamine has great influence on the thermal stabilities of products. Compound 2a showed better thermal stability as compared to other samples there was almost no weight loss until $200{ }^{\circ} \mathrm{C}$. This is persumably due to the greater stability of tosyl group. It is expected that tosyl group cleaves from nitrogen at $200{ }^{\circ} \mathrm{C}$ and then gradual thermal decomposition started as shown in Fig. 1. 


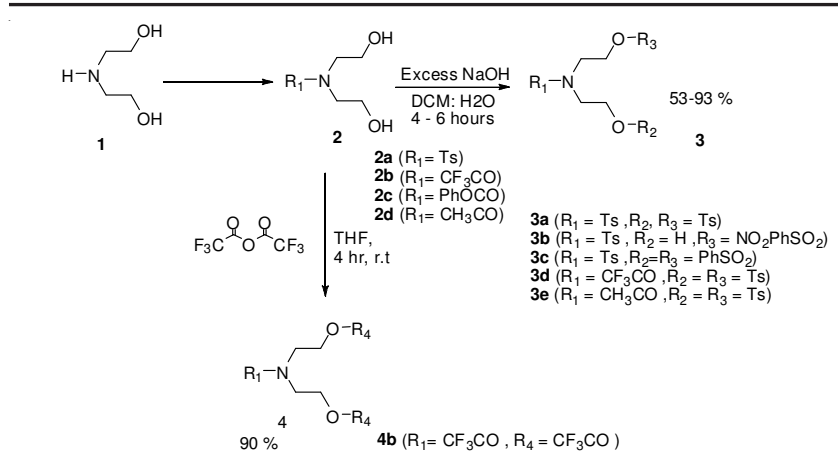

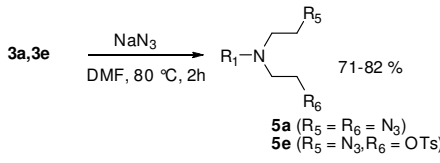

$3 b, 3 c, 3 d, 3 e, 4 b$ and $5 e$ are new compounds

Scheme-I: Synthetic pathway for diethanolamine derivatives

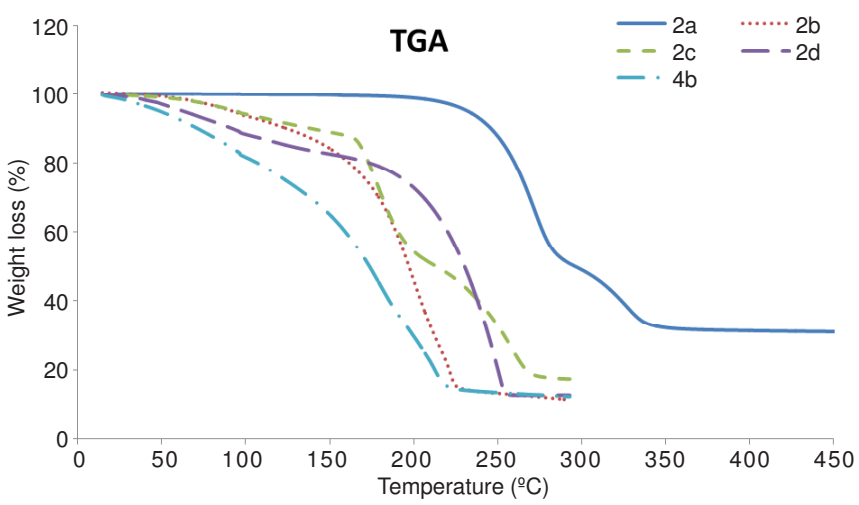

Fig. 1. Thermal decomposition as weight per cent loss (W \%) and heat flow $(\mathrm{mW})$ versus temperature $\left(\mathrm{T} /{ }^{\circ} \mathrm{C}\right)$

Thermal stability of $\mathbf{2 b - 2 d}$ was almost similar in which initially presumably $\mathrm{N}$ substituent detaches, followed by the decomposition of diethanolamine as shown in Fig. 1. Final decomposition temperatures $\left(225-300^{\circ} \mathrm{C}\right)$ were high that could be due to loss of hydrogen bonding among hydroxyl groups of diethanolamine ${ }^{23}$. The compound $\mathbf{4 b}$ have no hydroxyl groups, therefore it was comparatively less stable among the derivatives studied. In case of $\mathbf{4 b}$ significant thermal decomposition occured at $40^{\circ} \mathrm{C}$ and completed almost at $225^{\circ} \mathrm{C}$. For comparative studies, activation energies, enthalpies and entropies of derivatives $\mathbf{2} \mathbf{a}-\mathbf{2 d}$ and $\mathbf{4 b}$ were calculated (Table1) using graphical data obtained from thermogravimetric analysis incorporated with curve-fitting software- the Battery $\operatorname{program}^{24}$.

\begin{tabular}{cccc}
\multicolumn{4}{c}{ TABLE-1 } \\
\multicolumn{4}{c}{ ACTIVATION ENERGY, ENTHALPY, ENTROPY } \\
AND ORDER OF REACTION OF 2a-2d AND 4b \\
\hline \multirow{2}{*}{ Samples } & Activation & Enthalpy & Entropy \\
& energy $(\mathrm{J} / \mathrm{mol})$ & $(\mathrm{J} / \mathrm{mol})$ & $(\mathrm{J} / \mathrm{mol} . \mathrm{K})$ \\
\hline $\mathbf{2 a}$ & 258727.88 & 257065.08 & 2691.64 \\
$\mathbf{2 b}$ & 9238.56 & 7575.76 & -193.25 \\
$\mathbf{2 c}$ & 12898.57 & 11235.77 & -145.07 \\
$\mathbf{2 d}$ & 82219.33 & 80556.53 & 686.86 \\
$\mathbf{4 b}$ & 4040.54 & 2377.74 & -268.69 \\
\hline
\end{tabular}

Statistical analysis: Using one way ANOVA system, the analysis of variance for thermal analysis was performed for diethanolamine derivatives $\mathbf{2 a - 2} \mathbf{d}$ and $\mathbf{4 b}$ to observe the effect of temperature. It was observed by ANOVA results that except $\mathbf{4 b}$ and $\mathbf{2 a}$ there is insignificant difference among these derivatives. Compound 2a showed comparitivly greater stability among these derivatives. However in case of derivative $\mathbf{4 b}$, decomposition became significant in temperature range 15 $200{ }^{\circ} \mathrm{C}$.

Differential scanning calorimetry (DSC): The DSC thermograms of $\mathbf{2 a - 2 d}$ and $\mathbf{4 b}$ are compared in Fig. 2. All derivatives show first broad endothermic peak in their thermograms at $50-100{ }^{\circ} \mathrm{C}$ which could be due to their phase change.

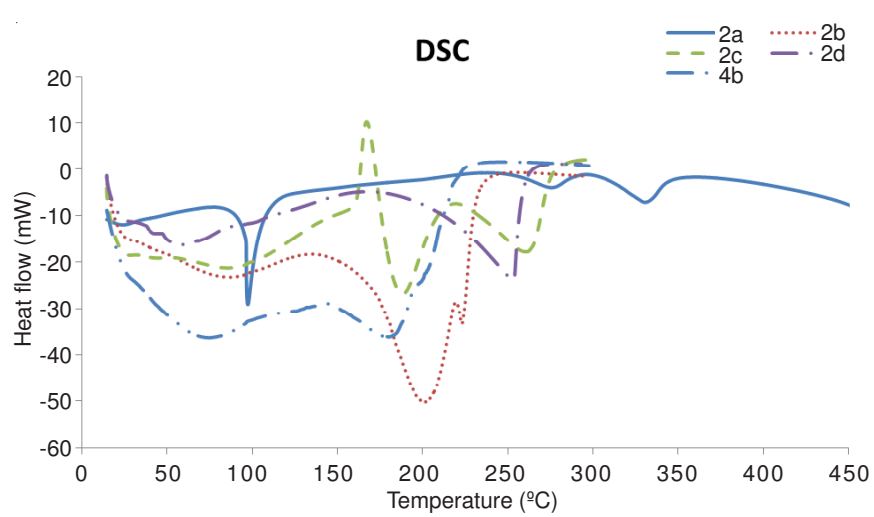

Fig. 2. DSC thermograms as heat flow (mW) versus temprature $\left({ }^{\circ} \mathrm{C}\right)$

The compound $\mathbf{2 a}$ showed a glass transition at temperature range $\mathrm{T}_{\mathrm{g}}\left(20-60^{\circ} \mathrm{C}\right)$ and characteristic endothermic peak of melting at $\mathrm{T}_{\mathrm{m}}\left(95^{\circ} \mathrm{C}\right)$. There was no endothermic or exothermic transition in temperature range of $115-250^{\circ} \mathrm{C}$. This might be due to the heat absorbed by $\mathbf{2 a}$ to increase its internal energy that leads to an endothermic peak of boiling at $270{ }^{\circ} \mathrm{C}$ followed by final glass transition of decomposition at $325{ }^{\circ} \mathrm{C}$. The compunds $\mathbf{2 b}, \mathbf{2 d}$ and $\mathbf{4 b}$ showed their endothermic peak of boiling at 200,175 and $70{ }^{\circ} \mathrm{C}$ respectively. The distinguished endothermic peak at $185^{\circ} \mathrm{C}$ for compound $2 \mathrm{c}$ could be due to the intermolecular cyclization and subsequent removal of phenoxy group as shown in Fig. 3. It is important to note there is no such intramolecular cyclization possiblity present in other studied compounds.

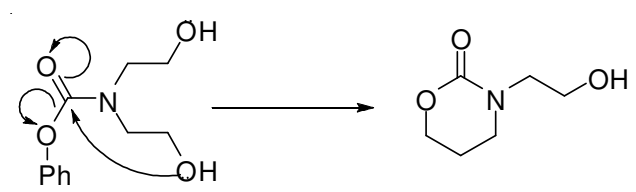

Fig. 3. Intermolecular cyclization of derivative $\mathbf{2 c}$

Heat capacity $\mathrm{C}_{\mathrm{p}}$ of $\mathbf{2 a - 2 d}$ and $\mathbf{4 b}$ was calculated by following formula.

$$
\mathrm{C}_{\mathrm{p}}=\frac{\{\mathrm{E} \times \mathrm{H} \times 60\}}{\left\{\mathrm{M} \times \mathrm{H}_{\mathrm{r}}\right\}}
$$

where $\mathrm{C}_{\mathrm{p}}$ is heat capacity, $\mathrm{E}$ is cell calibration constant (dimensionless) at a temperature of interest, $\mathrm{H}$ is heat flow ( $\mathrm{mW}$ ), 60 is conversion constant for minute to seconds, $\mathrm{M}$ is mass of sample and $\mathrm{H}_{\mathrm{r}}$ is heating rate $\left({ }^{\circ} \mathrm{C} / \mathrm{min}\right)$. The values of $\mathrm{C}_{\mathrm{p}}$ of $\mathbf{2 a - 2 d}$ and $\mathbf{4 b}$ have been measured for temperatures from 50-298 ${ }^{\circ} \mathrm{C}$ (Fig. 4). 


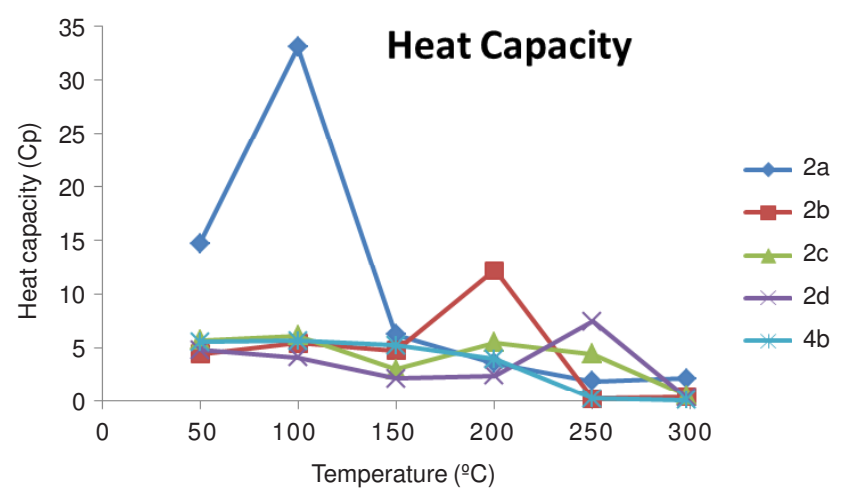

Fig. 4. Heat capictiy of samples

\section{Antioxidant activity}

$\mathrm{ABTS}^{\bullet+}$ radical cation decolurization assay: Antioxidant ability of synthesized compounds was studied in comparison with reference compound, Trolox ${ }^{25}$.

Diethanolamine derivatives (2a-5e) showed better ABTS radical scanvanging than reactant diethanolamine as shown in Fig. 5. These derivatives have TEAC value between 2.5-16 while precursor diethanolamine exibited 2.3 TEAC value. By definition, Trolox has a TEAC of 1 . As the TEAC of $\mathbf{2} \mathbf{c}$ is 16 , this shows that one molecule of $2 \mathbf{c}$ scavenges on average 16 times as much ABTS as Trolox. Among all derivatives 2c showed excellent antioxidant activity that may be due to phenolic moiety. Derivatives other than $\mathbf{2 a}$ and $\mathbf{3 b}$ showed average scanvanging of ABTS radical cations while $\mathbf{2 a}$ and 3b showed comparitivly poor scanvanging.

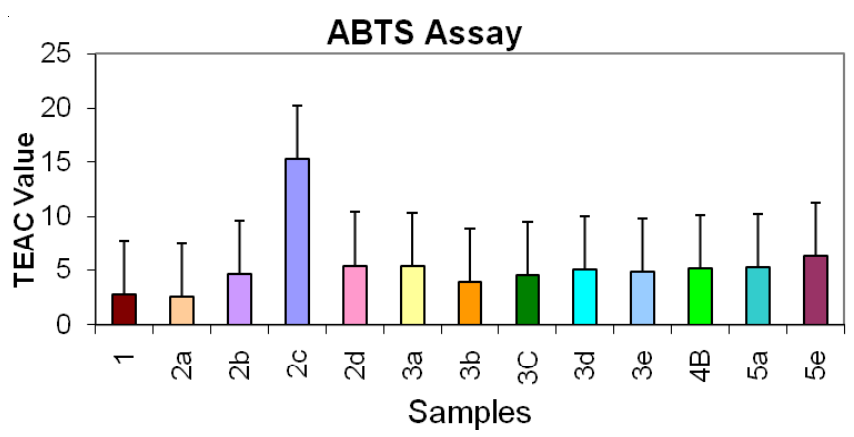

Fig. 5. ABTS radical scanvanging

FRAP Assay: The FRAP assay was carried out following method developed by Benzie and Strain ${ }^{20}$. Any antioxidant species with lower reduction potential than that of Fe(III) TPTZ salt $(0.7 \mathrm{~V})$ can reduce $\mathrm{Fe}^{3+}-\mathrm{TPTZ}$ to $\mathrm{Fe}^{2+} \mathrm{TPTZ}$. This reduction is monitored spectrophotometrically at $593 \mathrm{~nm}$. If a sample contains reducing components intense blue colour is appeared. The original method of Benzie and Strain uses a 4 min interval but we noted that the reaction/colour change is in progress even after 4 min interval. Therefore absorbance was measured at a 6 min interval after addition of sample to TPTZ reagent allowing the reaction to reach a steady state. The FRAP values of the samples were measured in comparison with a calibration curve obtained using iron(II) sulphate as the standard reductant.

Diethanolamine and its derivatives showed FRAP values in the range of 4-6. As graphical data showed that $\mathbf{2 a}, \mathbf{2 c}, \mathbf{3 c}$, 4b and 5e showed comparitively higher FRAP values than other derivatives, may be due to the presnece of high electron density as delocalisation in substituents of the derivatives. While 2b, 2d and 3f exibited comparitively lower FRAP values that can be attributed to the low electron density or absence of aromaticity (Fig. 6).

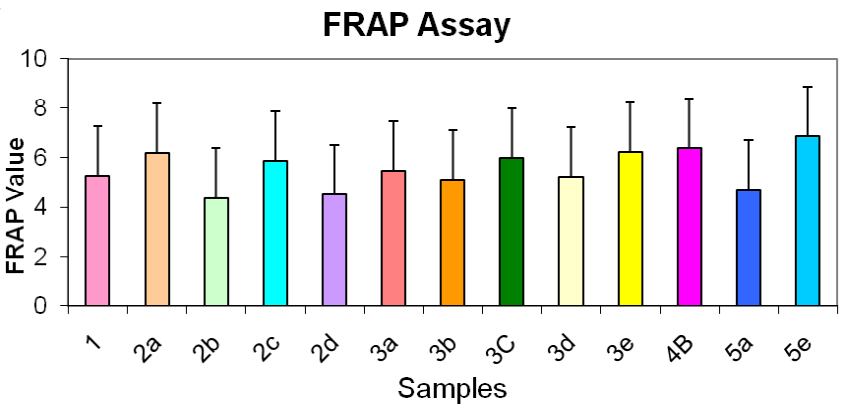

Fig. 6. FRAP result

Metal chelating activity: An important advantage of antioxidants is their ability to chelate/deactivate transition metals ${ }^{26}$, which possess the ability to catalyze hydroperoxide decomposition and Fenton-type reactions. Chelating agents may also serve as secondary antioxidants since they reduce redox potential, thereby stabilizes the oxidized forms of metal species. Therefore, the ion(II) chelating capacities of the samples were screened (Fig. 7).

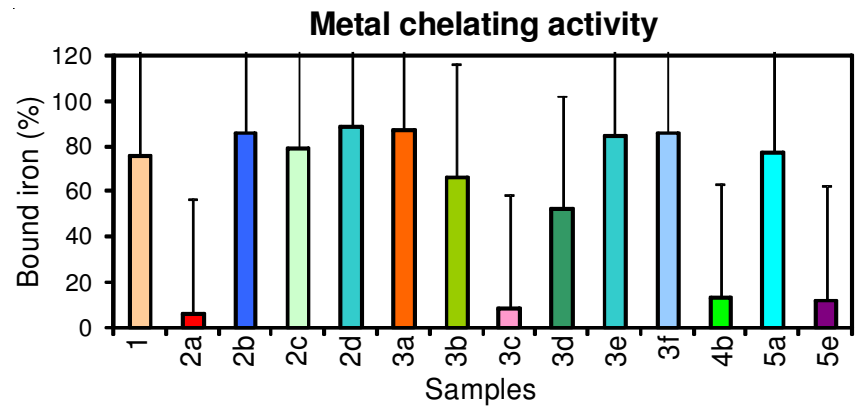

Fig. 7. Metal chelating ativity

Ferrozine forms complexes with $\mathrm{Fe}^{2+}$. In the presence of chelating agents, complex formation between ferrozine and $\mathrm{Fe}^{2+}$ is disrupted, as a result red colour of the complex is reduced which allows estimation of the chelating activity of the co-existing chelator. Interestingly, all derivatives were found to have metal chelating activity.

As the reactive oxygen species (ROS) generation is associated with redox active metal catalysis which involves chelating of metal ion. Diethanolamine derivatives showed good result in metal chelating activity as compared to ABTS assay and FRAP assay. Diethanolamine derivatives considerably interfered the formation of ferozine complex by capturing ferrous ions. All derivatives except 2a, scanvenged ferrous ions before its formation to ferrozine complex which may be due to the presence of $\mathrm{OH}$, protected alcohols and protected amine groups.

Comparitivly poor metal chelating activity of $\mathbf{2 a}$ may be due to bulky group (mention group here in bracket) attached with nitrogen which hindered chelate formation with ferrous ions. 
Antimicrobial activity: All the compounds except 3d, possessed antimicrobial activity against Escherichia coli, Staphylococcus aureus, Micrococcus luteus, Bacillus subtilis, Pasteurrella mutocida, Rhizopus oryzae, Salmonella typhi. None of the compounds was active against Pseudomonas aeruginosa (Table-2).

The solvent dichloromethane ( $\mathrm{S} 1)$ is used as negative control, in order to check the role of the solvent in inhibition. The samples were dissolved in dichloromethane. Ciprofloxacin (S2) was used as the standard antibacterial drug ketoconazole (S3) was used as the standard antifungal drug. Diethanolamine itself is a good antimicrobial agent and we expected synthesized diethanolamine derivatives may be more potent.

The compounds $\mathbf{2 a}, \mathbf{2 b}, \mathbf{2 c}, \mathbf{3 a}$ and $\mathbf{4 b}$ inhibited most of the pathogens used in the assay (Table-3). The broad antimicrobial activity of 2a and 3a might be related to the belonging of compounds to sulfonamide class of antimicrobials, as tosyl group has boosted the activity of diethanolamine. It is obvious from results that trifluoro group improved the antimicrobial strength of diethanolamine. Similary trifluoro group at nitrogen as well as on both oxygen imparted an astonishing strength to the parent molecule. It not only strengthened antimicrobial character of diethanolamine but also the mechanical behaviour of the parent compound. The compound $\mathbf{2 c}$ performed an average character. It added inhibition of some new organism to the diethanolamine's antimicrobial spectra that were not inhibited by diethanolamine before. This is attributed to phenoxy addition to nitrogen. Benzene sulphonyl group at both oxygen in 3c diminished the antimicrobial character of $\mathbf{2 a}$, this might be an inverse relationship of tosyl and benzene sulfonyl group, this must be related to structure activity relationship of the both groups.

The compound 3d showed no activity, it seems triflouro group has played an antagonistic role in tosyl activity, although independently $\mathbf{2 b}$ behaved an excellent microbial inhibitor. Similarly in 3e, the acetyl group acted as an inhibitor for tosyl attached at both oxygens. In $\mathbf{5 a}$, the azide group was silent.

Overall synthesized derivatives showed satisfactory results not only for gram positive, gram negative bacteria, but also for the fungus Rhizopus oryzae used in the assay.

\begin{tabular}{|c|c|c|c|c|c|c|c|c|}
\hline \multirow[b]{3}{*}{ Code } & \multicolumn{7}{|c|}{$\begin{array}{c}\text { TABLE-2 } \\
\text { MEAN ZONE OF INHIBITION BY MICROORGANISMS }\end{array}$} & \multirow{3}{*}{$\begin{array}{c}\text { Salmonella } \\
\text { typhi }\end{array}$} \\
\hline & \multicolumn{7}{|c|}{ Mean zone of inhibition of microorganisms } & \\
\hline & $\begin{array}{l}\text { Escherichia } \\
\text { coli }\end{array}$ & $\begin{array}{l}\text { Staphylococcus } \\
\text { aureus }\end{array}$ & $\begin{array}{l}\text { Micrococcus } \\
\quad \text { luteus }\end{array}$ & $\begin{array}{c}\text { Pseudomonas } \\
\text { aeruginosa }\end{array}$ & $\begin{array}{l}\text { Bacillus } \\
\text { subtilis }\end{array}$ & $\begin{array}{l}\text { Pasteurrella } \\
\text { mutocida }\end{array}$ & $\begin{array}{l}\text { Rhizopus } \\
\text { oryzae }\end{array}$ & \\
\hline $2 \mathbf{2 a}$ & $11.5 \pm 0.707$ & $10 \pm 1.414$ & $10.5 \pm 0.707$ & - & - & - & $10.5 \pm 0.707$ & $19 \pm 1.414$ \\
\hline $2 b$ & - & $15 \pm 1.414$ & $17.5 \pm 0.707$ & - & $14 \pm 1.414$ & $19 \pm 1.414$ & $15 \pm 1.414$ & $14 \pm 1.414$ \\
\hline $2 c$ & $17 \pm 1.414$ & $10 \pm 1.414$ & $14.5 \pm 0.707$ & - & - & - & $10.5 \pm 0.707$ & - \\
\hline 2d & - & - & $10.5 \pm 0.707$ & - & - & $13 \pm 1.414$ & $10.5 \pm 1.414$ & $13.5 \pm 2.12$ \\
\hline $3 a$ & - & $16 \pm 1.414$ & $16 \pm 1.414$ & - & $13 \pm 1.414$ & $10.5 \pm 0.707$ & $13 \pm 1.414$ & $14 \pm 1.414$ \\
\hline $3 \mathbf{b}$ & $21 \pm 1.414$ & $15 \pm 1.414$ & - & - & - & - & $10.5 \pm 0.707$ & - \\
\hline $3 c$ & - & - & - & - & - & - & $9 \pm 1.414$ & - \\
\hline 3d & - & - & - & - & - & - & - & - \\
\hline $3 e$ & - & - & $10.5 \pm 0.707$ & - & - & - & - & - \\
\hline $4 b$ & $19 \pm 1.414$ & $11.5 \pm 0.707$ & $15.5 \pm 0.707$ & - & $17 \pm 1.414$ & $14 \pm 1.414$ & $14 \pm 1.414$ & $17 \pm 1.414$ \\
\hline $5 a$ & $10.5 \pm 0.707$ & - & - & - & - & - & $14.4 \pm 2.121$ & - \\
\hline 1 & $13 \pm 1.414$ & - & $20 \pm 1.414$ & - & $10.5 \pm 0.707$ & $15.5 \pm 0.707$ & $11 \pm 1.414$ & 15 \\
\hline S1 & - & - & - & - & - & - & - & - \\
\hline $\mathrm{S} 2$ & 30 & 30 & 30 & 30 & 30 & 30 & 30 & 30 \\
\hline S3 & 22 & 22 & 22 & 22 & 22 & 22 & 22 & 22 \\
\hline
\end{tabular}

\begin{tabular}{|c|c|c|c|c|c|c|c|c|}
\hline \multirow[b]{3}{*}{ Code } & \multicolumn{7}{|c|}{$\begin{array}{c}\text { TABLE-3 } \\
\text { PERCENTAGE INHIBTION BY PATHOGENIC MICROBES }\end{array}$} & \multirow[b]{3}{*}{$\begin{array}{c}\text { Salmonella } \\
\text { typhi }\end{array}$} \\
\hline & \multicolumn{7}{|c|}{ Inhibition by pathogenic microorganisms (\%) } & \\
\hline & $\begin{array}{l}\text { Escherichia } \\
\text { coli }\end{array}$ & $\begin{array}{c}\text { Staphylococcus } \\
\text { aureus }\end{array}$ & $\begin{array}{l}\text { Micrococcus } \\
\quad \text { luteus }\end{array}$ & $\begin{array}{l}\text { Pseudomonas } \\
\text { aeruginosa }\end{array}$ & $\begin{array}{l}\text { Bacillus } \\
\text { subtilis }\end{array}$ & $\begin{array}{l}\text { Pasteurrella } \\
\text { mutocida }\end{array}$ & $\begin{array}{l}\text { Rhizopus } \\
\text { oryzae }\end{array}$ & \\
\hline $2 a$ & 38.33 & 33.33 & 35 & - & - & - & 47 & 63.3 \\
\hline $2 \mathbf{b}$ & - & 50 & 58.33 & - & 46.7 & 63.33 & 68 & 46.7 \\
\hline $2 c$ & 56.66 & 33.33 & 48.33 & - & - & - & 47 & - \\
\hline 2d & - & - & 35 & - & - & 43.33 & 47 & 0.45 \\
\hline 3a & - & 53.33 & 53.33 & - & 43.3 & 35 & 59 & 46.7 \\
\hline 3b & 70 & 50 & - & - & - & - & 47 & - \\
\hline $3 \mathbf{c}$ & - & - & - & - & - & - & 40 & - \\
\hline 3d & - & - & - & - & - & - & - & - \\
\hline $3 e$ & - & - & 35 & - & - & - & - & - \\
\hline $4 b$ & 63.33 & 38.33 & 51.7 & - & 56.7 & 46.7 & 63.6 & 56.7 \\
\hline $5 a$ & 35 & - & - & - & - & - & 65.4 & - \\
\hline 1 & 43.3 & - & 66.7 & - & 35 & 51.7 & 50 & 51.7 \\
\hline S1 & - & - & - & - & - & - & - & - \\
\hline S2 & 100 & 100 & 100 & 100 & 100 & 100 & 100 & 100 \\
\hline S3 & 100 & 100 & 100 & 100 & 100 & 100 & 100 & 100 \\
\hline
\end{tabular}




\section{Conclusion}

We have described herein synthesis, biological and thermal evaluation of a series of diethanolamine derivatives. Order of thermal stabilities of free flowing oils $\mathbf{2} \mathbf{b}-\mathbf{2} \mathbf{d}$ and solid derivative 2a was $\mathbf{2 a}>\mathbf{2 c}>\mathbf{2 d}>\mathbf{2 b}>\mathbf{4 b}$. Compounds $\mathbf{2 a}$ and $\mathbf{4 b}$ had significant difference in thermal decompositional behaviour while $\mathbf{2 b - 2 d}$ exhibited insignificant difference. The activation energies of oils $\mathbf{2} \mathbf{b}-\mathbf{2 d}$ increased as function of thermal stability of $\mathrm{N}$-substitution at diethanolamine. All the compounds were tested for their in vitro antimicrobial and antioxidant activities. Regarding antioxidant activity all derivatives showed moderateto-good FRAP and ABTS result and considerably excellent metal chelating activity and derivative $2 \mathrm{c}$ having phenoxyl group exhibited excellent ABTS radical scavenging among all derivatives. Studies showed that compounds $\mathbf{2 a}, \mathbf{2 b}, \mathbf{3 a}$ and $\mathbf{4 b}$, having tosyl and triflouro group as a substituent were found to be the most potent member against used microorganisms and pathogenic microbes as compared to others.

\section{ACKNOWLEDGEMENTS}

The authors thank Higher Education Commission Pakistan for financial support.

\section{REFERENCES}

1. K.H. Beyer, W.F. Bergfeld, W.O. Berndt, R.K. Boutwell, W.W. Carlton, D.K. Hoffmann and A.L. Schroeter, J. Am. Coll. Toxicol., 2, 183 (1983).

2. Diethanolamine NIEHS/NTP March 22 (2002).

3. E. Lukevics, L. Liberts and M.G. Voronkov, Russ. Chem. Rev., 39, 953 (1970).

4. S.Y. Jung and H. Yoshida, J. Therm. Anal. Calorim., 89, 681 (2007).

5. M. Day, A.V. Nawaby and X. Liao, J. Therm. Anal. Calorim., 86, 623 (2006).
6. C.C. Garcia, P.I. B. M. Franco, T.O. Zuppa, N.R.A. Filho and M.I.G. Leles, J. Therm. Anal. Calorim., 87, 645 (2007).

7. J. Dweck and M.S. Sampaio, J. Therm. Anal. Calorim., 75, 385 (2004).

8. B. Kowalski, Thermochim. Acta, 184, 49 (2001).

9. V.T. Yilmaz, Y. Topcu, F. Yilmaz and C. Thoene, Polyhedron, 20, 3209 (2001).

10. J. Madarasz, P. Bombicz, M. Czugler and G. Pokol, Polyhedron, 19, 457 (2000).

11. K.F. Ball, J.G. Bostick and T.J. Brennan, Fuel Lubricity from Blends of a Diethanolamine Derivative and Biodiesel (1999).

12. M. Koca, S. Servi, C. Kirilmis, M. Ahmedzade and C. Kazaz, Eur. J. Med. Chem., 40, 1351 (2005).

13. K. Baillie, A.A.R. Thompson, J.B. Irving, M.G.D. Bates, A.I. Sutherland, W. MacNee, S.R.J Maxwell and D.J. Webb, QJM, 102, 341 (2009).

14. A.V. Bailey, G.J. Boudreoux, G. Sumerell and A. Novak, J. Am. Oil Chem. Soc., 55, 835 (1978).

15. M. Agbandjet, T.C. Jenkins, R. McKenna, A.P. Reszka and S. Neidle, J. Med. Chem., 35, 1418 (1992).

16. C. Fleck, E. Karge, S. Loy, K.J. Wennek, M. Listing and H. Oelschläger, Arzneimittelforschung, 53, 221 (2003).

17. P.L. Ferrarini, M. Badawneh, F. Franconi, C. Manera, M. Miceli, C. Mori and G. Saccomanni, Farmaco, 56, 311 (2001).

18. Z.D. Petrovic, D.H. Litina, E. Pontiki, D. Simijonovic and V.P. Petrovic, Bioorg. Chem., 37, 162 (2009).

19. H. Bhutani, S. Singh, K.C. Jindal and A.K. Chakraborti, J. Pharm. Biomed. Anal., 39, 892 (2005).

20. I.F.F. Benzie and J.J. Strain, Method. Enzymol., 299, 5 (1999).

21. T.C. Dinis, V.M. Maderia and L.M. Almeida, Arch. Biochem. Biophys., 315, 161 (1994).

22. Barkatullah, M. Ibrar, N. Muhammad and L. Tahir, J. Med. Plants Res., 6, 2105 (2012).

23. S.T. Kim, J.W. Kang, J.S. Lee and B.M. Min, Korean J. Chem. Eng., 28, 2275 (2011).

24. A. Afzal, H.M. Siddiqi, N. Iqbal and Z. Ahmad, J. Therm. Anal. Calorim. 111, 247 (2013).

25. J.N. Miller, R. Evans, M.J. Davies, V. Gopinathan and A. Milner, Clin. Sci., 4, 407 (1993)

26. V.N. Quang and B.E. Jong, J. Med. Plants Res., 5, 2798 (2011). 